\title{
External environment impact on business performance in digital creative industry: Dynamic capability as mediating variable
}

\author{
Romat Saragih $^{1, *}$, Agus Rahayu ${ }^{2}$, Lili Adi Wibowo ${ }^{2}$ \\ ${ }^{1}$ Faculty of Communication and Business, Univesitas Telkom, Bandung, Indonesia \\ ${ }^{2}$ Faculty of Economics and Business Education, Universitas Pendidikan Indonesia, Bandung, Indonesia
}

\section{A R T I C L E I N F O}

\section{Article history:}

Received 23 May 2017

Received in revised form

15 July 2017

Accepted 2 August 2017

\section{Keywords:}

Business performance

Digital creative industry

Dynamic capability

External environment

\begin{abstract}
A B S T R A C T
All companies face the challenge on how to create a sustainable competitive advantage, especially in the rapidly changing business environment, which is dynamic and highly turbulent. Digital creative industry is an industry that combines elements of creative and digital in its products and services. Indonesia has great potential in the development of digital creative industry, since their digital creative actors are able to generate competitive creative contents. This study aims to explore the impact of dynamic capability as a mediator of business performance in the face of external environment changing in the digital creative industries in Indonesia. A total of 96 respondents participated in this study. This study used a quantitative method with survey approach. The analysis technique used is structural equation modeling (SEM) to test the hypothesis and SmartPLS 3.0 Program as a tool in data processing. This study looked at the dynamic capability as the emerging paradigm of modern business that drive sustained high performance in the rapidly changing environment. The limitation of this research is the scope of research which only covers some areas in Indonesia, so it is expected that further research can expand the area coverage.
\end{abstract}

(C) 2017 The Authors. Published by IASE. This is an open access article under the CC BY-NC-ND license (http://creativecommons.org/licenses/by-nc-nd/4.0/).

\section{Introduction}

Nowadays, the development of business environment takes place in a fast, dynamic and turbulent way. The dynamism of technological change and product innovation also affect the development of various industrial fields. The environment changing conditions draw attention for researchers to better understand the role of strategic management discipline in contributing to the improvement of business performance (Venkatraman and Ramanujam, 1986; Deshpandé et al., 2013; Gunter et al., 2016). Business performance is the key factor to survive in global competition. Continuous strategy adjustment is the process in response to dynamic and turbulent business environment (Dess et al., 2006).

Digital creative industry is one of the creative industries which should have the ability to respond rapidly changing business environment. According to data from the Ministry of Tourism and Creative Economy, creative industries contributed an average

\footnotetext{
* Corresponding Author.

Email Address: saragih@ypt.or.id (R. Saragih) https://doi.org/10.21833/ijaas.2017.09.008

2313-626X/C 2017 The Authors. Published by IASE.

This is an open access article under the CC BY-NC-ND license

(http://creativecommons.org/licenses/by-nc-nd/4.0/)
}

of $7.13 \%$ of gross domestic product in the period 2010-2014. Meanwhile, the creative industries in 2015 contributed IDR 642 trillion to GDP, with employment reaching 11.8 million people or 10.7 percent of the national workforce. Digital creative industries generate creative information technology products and become the solution of people's daily lives (Mangematin et al., 2014). Digital creative industry consists of: 1) Software and Application Industry, 2) Education Software Industry, 3) Game Industry, 4) Animation Industry, and 5) Digital Music Industry. The industry is also optimizing various creative fields such as art and music with the intermediary of information technology.

The number of companies in the digital creative industry in recent years experienced the highest growth of up to $16 \%$ per year (MIKTI, 2016). Based on information from the Deputy of Research (TEMPO.CO, 2016)), the industry's competitive position which is relatively low with growth of $8.81 \%$ compared to growth at the global level, which reached $16 \%$. One of the causes for low growth was because of the tendency of customer preferences in Indonesia, which is still oriented to imported products. They think that foreign products have better quality than domestic products. MIKTI (2016) showed that $93 \%$ of the domestic software industry actors feel their software production are not 
appreciated by their own country, 52\% complained of inadequate availability of human resources, $12.5 \%$ related problems: piracy, lack of capital, corruption and lack of innovation in making software (MIKTI, 2016).

Based on data from the BPSI (2016), the number of MSMEs (Micro, Small and Medium Enterprises) in Indonesia reached 56.5 million units. The large number of MSMEs is a potential market for the digital creative industries because at present only small number of MSMEs use information technology (IT) to support their business activities. This condition is supported by the rising of Internet users from year to year. Based on data from APJII (2016), Internet users in Indonesia in 2016 amounted to 102.8 million and increased in 2017 to reach 112.6 million. In addition, based on the same data source shows that smartphone penetration in Indonesia amounted to $40.4 \%$ in 2016 and increased to $43.2 \%$ in 2017.

Business performance is the end result of all business activities in a particular period. According to Walker et al. (1996), there are three main attributes used in the performance measurement include effectiveness, efficiency, and adaptiveness. One of the factors that determine the success of business performance is the company's ability to adapt to environmental changes dynamically (Lofsten, 2014). According to Nieves and Haller (2014), dynamic capability is the ability to utilize internal resources owned, adapted to the demands of external dynamics, which in turn will improve the organization's business performance. Strategy implementation of dynamic capabilities can be conducted by sensing, reconfigure, integrate and coordinate resources / internal capabilities of the company, including operational capability, financial capability, marketing capability, employees capability, and innovation capability, which is adapted to the dynamics external environment, both industrial environment and the macro environment, so as to create a competitive advantage (Felier and Teece, 2014).

The study that considers the dynamic capabilities within an organization are still limited, therefore this research tried to overcome the gap by exploring the impact of dynamic capability as a mediator of business performance in the face of external environment dynamics in the digital creative industry in Indonesia.

According to Saragih and Anggadwita (2016), the company must have the dynamic capability and distinctive competence in achieving a sustainable competitive advantage as a strategy in the face of competition in the digital creative industry, especially software development. The results of this study are expected to contribute in delivering information, knowledge and stakeholders associated with the digital creative industry, including Indonesian government, academia, investors, entrepreneurs, and the community with a focus on the growth of the digital creative industry in Indonesia.

\section{Literature review}

According to Beamish et al. (2008), the business environment is consisted of a double layer i.e. the outermost layer called the macro environment that consists of the elements: political, technological, legal, social/cultural, demographic, environmental, and international. Meanwhile, the inner layer is called the local environment or the industry environment, which is also called the Porter's Five Forces, consisting of components: substitutes, buyers, suppliers, competitors and new entrants. Macro environmental issues generally affect many industries; however, the main concern is the elements that affect the industry growth. Meanwhile, the components that should be considered in the environmental industry are those that can affect profitability and the company's position in the competition.

Wheelen and Hunger (2012) gave another term for macro environment as a social environment consisting of elements: economic power, the power of technology, the power of the political-legal, and the strength of social/cultural. Meanwhile, the environment industry is termed task environment consists of components: shareholders, suppliers, labor/unions, competitors, trade associations, communities, creditors, customers, specific interest groups, and Government. Environmental organizations or internal environment is consisted of components: structure, culture, and resources.

On the other hand, Hitt et al. (2012) divided environments into: public environment, industry environment, and competitors' environment. Public environment consists of wider social dimension that affects an industry or company. The industry environment is a set of factors that directly influence the company as well as competitive actions and responses, namely: the threat of new entrants, bargaining power of supplier, bargaining power of buyer, the threat of substitute, and the intensity of the companies' rivalry. The competitors' environment is efforts to understand how other companies compete, identify goals, strategies, assumptions, and capabilities. Macro external environment is sometimes called the spacious environment if the changing environment may impact the business widely in almost all industries. According to Pearce and Robinson (2008), the factors of external macro environment consist: (1) economy; (2) social; (3) political; (4) technology; and (5) ecology.

Dynamic capabilities are the ability of the company to integrate, build and reconfigure of internal and external competence to cope with the rapid changes of environment (Teece et al., 1997). According to Rothaermel (2015), dynamic capabilities are a model that emphasizes on the company's capacity in modifying and improving its resources to improve and maintain competitiveness constantly on environmental change. The company should be able to create, deploy, modify, reconfigure, and upgrade the existing resources to provide value 
to the customers or make low costs production in the face of dynamically changing environment.

Based on the process perspective, Eisenhardt and Martin (2000) proposed a broad definition that dynamic capabilities are a series of specific processes and identifiable such as product development, strategic decision making, and alliances. Zollo and Winter (2002) from the routine perspective defined the dynamic capabilities as a learn pattern and collective activities directed to the development and adaptation of the organization's operational routine. Zahra et al. (2006) on the entrepreneurial perspective, dynamic capabilities defined as the ability to reconfigure the corporate resource and routines in decision making. Meanwhile, Grant (2010) also mentions the term dynamic capability refers to the ability of companies in integrating, building, and reconfiguring of internal and external competence to respond to rapid environmental change.

Dynamic capabilities are different with RBV for two main reasons: first, $\mathrm{RBV}$ is static, which means not sensitive to environmental changes, while the dynamic capabilities are able to handle environmental changes. Second, the RBV theory focuses on how to best utilize the company's resources while dynamic capabilities focus on the best ways to integrate, renew, reconfiguration, and create a resource. According to Teece et al. (1997), from the perspective of RBV, companies create wealth through rational alternatives selection between the investment potential (in a set of resources). The focus of the RBV is the utilization of the resources of company or asset owned to create profits. In contrast, dynamic capabilities designed to create advantages for companies operating in an environment with rapid technological change, with the goal of maintaining a competitive advantage.

Business performance is a concept that used to assess the business performance activities. According to Wheelen and Hunger (2012), business performance is the outcome of the implementation of strategic management. A similar definition is also presented by Mulyadi (2003) that the performance is the success of personnel, team, or organization in realizing the strategic goals that have been set before with the expected behavior. Business performance can also be defined as the factor used to measure the impact of the company strategy.

Periodic performance measurement is required by every organization, both profit and nonprofit organizations. According to Jaworski and Kohli (1993), business performance can be measured from the financial performance and the market performance. Similar with that opinion, Deshpandé et al. (1993) stated that business performance is measured from profitability, company size, market share, and sales growth. Meanwhile, according to Kaplan and Norton (2006) to ensure that the strategies are executed as planned, the company's business performance can be measured by the balance between financial and non-financial factors, through measurement of aspects: 1) financial perspective, 2) customer perspective, 3) internal process perspective, and 4) learning and growth perspective. The measurement models known as the Balanced Scorecard (BSC). Dimensions of performance measurement using the balanced scorecard is relatively widely used in the performance measurement both in large enterprises and small and medium enterprises (Pelhalm, 2000).

\section{Research method}

This study used quantitative methods with the descriptive and verificative approach. Descriptive research is used to obtain an overview of the business in the digital creative industries in Indonesia, as well as analyzing the characteristics and conditions of empirical research variables which includes business performance, dynamic capability, and the external environment. Verification research used to test the hypothesis and analyze how the relationships between variables, and to identify the influence between variables. SmartPLS program is used for SEM analysis of data processing in order to test the feasibility of measurement models and structural models.

The population of this study is all companies engaged in digital creative industries spread throughout Indonesia with products and services: software and applications, education software, game industry, animation industry, digital music, and maintenance services. However, the focus of research is the cluster areas of Jakarta and Bandung. Based on data from ASPILUKI (2017), 83\% of the total 254 listed digital creative industries are located in Jakarta and Bandung. Primary data was obtained from the questionnaire given to the respondents directly.

Individuals who became the respondents selected were: the CEO, senior leader, owner and senior staff who understand the creative digital industries. Meanwhile, the secondary data obtained from the BPSI (2016), business incubator unit of PT. Telkom, the report of the Ministry of tourism and the creative industries, Creative Economic Agency, and others. The sampling technique used in this research is simple random sampling. According to Silalahi (2012), the number of samples for the population below 1000, the researchers need a large sample ratio (approximately 30\%), then the number of samples from 254 companies is 76 samples of the company. Meanwhile, according to Ghozali (2008), data processing with PLS method requires a minimum sample of 50 samples (can also range from 30 to 100 samples). Thus, the number of samples in this study set as many as 96 respondents to get a higher level of accuracy in data processing.

The study consists of three variables include external environment as an independent variable, dynamic capabilities as a mediating variable, and business performance as dependent variable. The external environment variable in this study consists of macro environment and industrial environment dimensions, where the macro environment consists 
of the following factors: (1) technological change, (2) economic change, (3) regulation change, and (4) social/cultural change, and industrial environmental consists of the following factors: (1) bargaining power of buyers, (2) bargaining power of suppliers, (3) threat of substitute products, (4) threat of new entrants, and (5) rivalry among competing firms in the industry. Meanwhile, the dynamic capabilities in this study consist of dimensions: (1) sensing capabilities, (2) reconfiguration capabilities, (3) integration capabilities, and (4) coordinating capabilities. Furthermore, the business performance variables in this study are set by four perspectives, namely: (1) financial perspective, (2) customer's perspective, (3) internal process perspective, and (4) learning and growth perspective. The hypothesis of this study is "the dynamic capability has major influence as mediator to the external environment impact on business performance."

\section{Result and discussion}

\subsection{Respondents profile}

Digital creative industries experience rapid development, both at the global, regional and domestic. This development is also driven by the development of technology that is getting better and faster. The rivalry between digital creative industry is also very high, so that every company engaged in the field of digital creative industry is always trying to innovate in various fields, including attracting potential customers in accordance with the dynamism of the changing environment, both the changes of technological and lifestyle. The survey was conducted for 96 companies engaged in the digital creative industry with profile as shown in Table 1.

Profile of respondents based on the position showed that $66 \%$ as a manager or senior leader, $21 \%$ as director of the company, $7 \%$ as senior staff employees, respectively $3 \%$ as a supervisor and owner/commissioner. It shows that the respondent is people who have competence and a good knowledge of digital creative industries in Indonesia. Based on the work experience of respondents in the digital creative industry, $34 \%$ have work experience over 15 years, $26 \%$ have work experience 5-10 years, $22 \%$ have work experience $11-15$ years, and $18 \%$ have a work experience of less than 5 years. Based on the expertise in the field of IT, $90 \%$ of respondents have IT expertise, while the remaining $10 \%$ of respondents have expertise in other fields, such as accounting software, administration, graphic, operational, and others.

Based on the results of the study showed that $22 \%$ are Incorporated Companies (Inc.), and 24\% are Comanditaire Venotschap (CV). Meanwhile, most of companies in the digital creative industries in this study as much as $54 \%$ are not a legal entity both CV and Inc. The data illustrates that there are still many digital creative company in Indonesia that only has the status of individual businesses. The majority of the company's digital creative industries as much as $60 \%$ operational in 1999-2010, respectively $20 \%$ operational before 1999 and after 2010. Based on the number of employees, $45 \%$ of companies have employees between 11-20 people, 33\% of companies have fewer than 10 employees, and $22 \%$ of companies have more than 20 employees. It shows that the majority of the company's digital creative industry in Indonesia is still categorized in small and medium scale enterprises.

Table 1: Respondents profile

\begin{tabular}{|c|c|}
\hline Description & Total (\%) \\
\hline \multicolumn{2}{|l|}{ RESPONDENTS' PROFILE } \\
\hline \multicolumn{2}{|l|}{ Respondents' Position: } \\
\hline Owner/Commissioner & 3 \\
\hline Director & 21 \\
\hline Manager & 66 \\
\hline Supervisor & 3 \\
\hline Senior Staff & 7 \\
\hline \multicolumn{2}{|l|}{ Working Experiences: } \\
\hline$<5$ years & 22 \\
\hline $5-10$ years & 26 \\
\hline $11-15$ years & 18 \\
\hline$>15$ years & 34 \\
\hline \multicolumn{2}{|l|}{ Expertise: } \\
\hline Information Technology & 90 \\
\hline Others & 10 \\
\hline \multicolumn{2}{|l|}{ BUSINESS PROFILE } \\
\hline \multicolumn{2}{|l|}{ Business Legal Entities: } \\
\hline 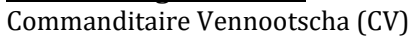 & 24 \\
\hline Incorporated Company (Inc.) & 22 \\
\hline Others & 54 \\
\hline \multicolumn{2}{|l|}{ Operating Years: } \\
\hline$<1999$ & 20 \\
\hline $1999-2010$ & 60 \\
\hline$>2010$ & 20 \\
\hline \multicolumn{2}{|l|}{ Number of Employees: } \\
\hline$<11$ people & 33 \\
\hline $11-20$ people & 45 \\
\hline$>20$ people & 22 \\
\hline \multicolumn{2}{|l|}{ Marketing Coverage: } \\
\hline Local & 6 \\
\hline National & 71 \\
\hline International & 5 \\
\hline Local dan National & 2 \\
\hline National dan International & 1 \\
\hline Local, National, dan International & 15 \\
\hline \multicolumn{2}{|l|}{ Products/Services Offered: } \\
\hline$\overline{\text { Digital Music }}$ & 2.1 \\
\hline Game/Entertaint & 3.1 \\
\hline Maintenance Service & 6.3 \\
\hline Education Software & 10.4 \\
\hline Animation & 79.2 \\
\hline Software and Application & 80.2 \\
\hline Others & 16.7 \\
\hline \multicolumn{2}{|l|}{ Growth of Profit: } \\
\hline $0 \%-10 \%$ & 7 \\
\hline $10 \%-20 \%$ & 69 \\
\hline $20 \%-30 \%$ & 15 \\
\hline$>30 \%$ & 9 \\
\hline
\end{tabular}

Based on the marketing coverage, $71 \%$ of companies have national marketing areas; respectively $6 \%$ and $5 \%$ of companies that have marketing areas locally and internationally; while $15 \%$ of companies have a marketing area locally, nationally and internationally; and only $2 \%$ that marketing includes local and national area. This showed that the majority of the company's digital creative industry in Indonesia operate and have the same market area in the domestic market. The identification based on products/services being 
offered shows that $80.2 \%$ of companies offer software and application product, $79.2 \%$ of companies also offer digital animation product, $10.4 \%$ of companies offer education software product, $6.3 \%$ of companies only offer maintenance service, $3.1 \%$ of companies only offer games product, and $2.1 \%$ offer digital music products, while $16.7 \%$ offer other products or services. Over the past three years by $69 \%$ company profit growth between $10 \%$ $20 \%$, and $15 \%$ experienced growth of between $20 \%$ - $30 \%$. The remaining $7 \%$ only grow below $10 \%$, and $9 \%$ experienced growth above 30\%. Most of company profit growth above $10 \%$, which indicates that the growth of digital creative industry in Indonesia is still promising.

\subsection{The results of hypothesis testing}

Data analysis techniques to test the hypothesis of this research use Structural Equation Modeling (SEM) with Partial Least Square (PLS) approach, which is assisted by using the application software of SmartPLS version 3.0. Stages of the analysis conducted in the PLS is a model measurement (outer model) and structural model (inner model). Model measurement model describes the proportion of variance of each manifest variable (indicators) that can be explained in a latent variable. Through this model measurement can also be known which indicators are more dominant in the formation of the latent variables. After the model measurement, each latent variable described, followed by a structural model that will assess the effect of each latent variable independent (exogenous latent variable) to the latent variable dependent (endogenous latent variable), to determine the influence of dynamic capabilities as mediator/intervening variable.

\subsubsection{Model measurement analysis (Outer model)}

Model measurement analysis conducted in this study uses a reflective structure, which is obtained by weighting factors that can be assessed by the validity of each indicator, and tested the construct reliability of the variables studied. There are 13 latent variables in this study, consisting of 3 latent variables in the second order and 10 latent variables in the first order, and consist of 34 manifest variables (indicator) as Table 2 below. Indicators that have loading factor of less than 0.50 will be reduced or dropped from the model, while the Composite Reliability (CR) is considered satisfactory is greater than 0.70 .

Table 2: Loading factor measurement of second order confirmatory

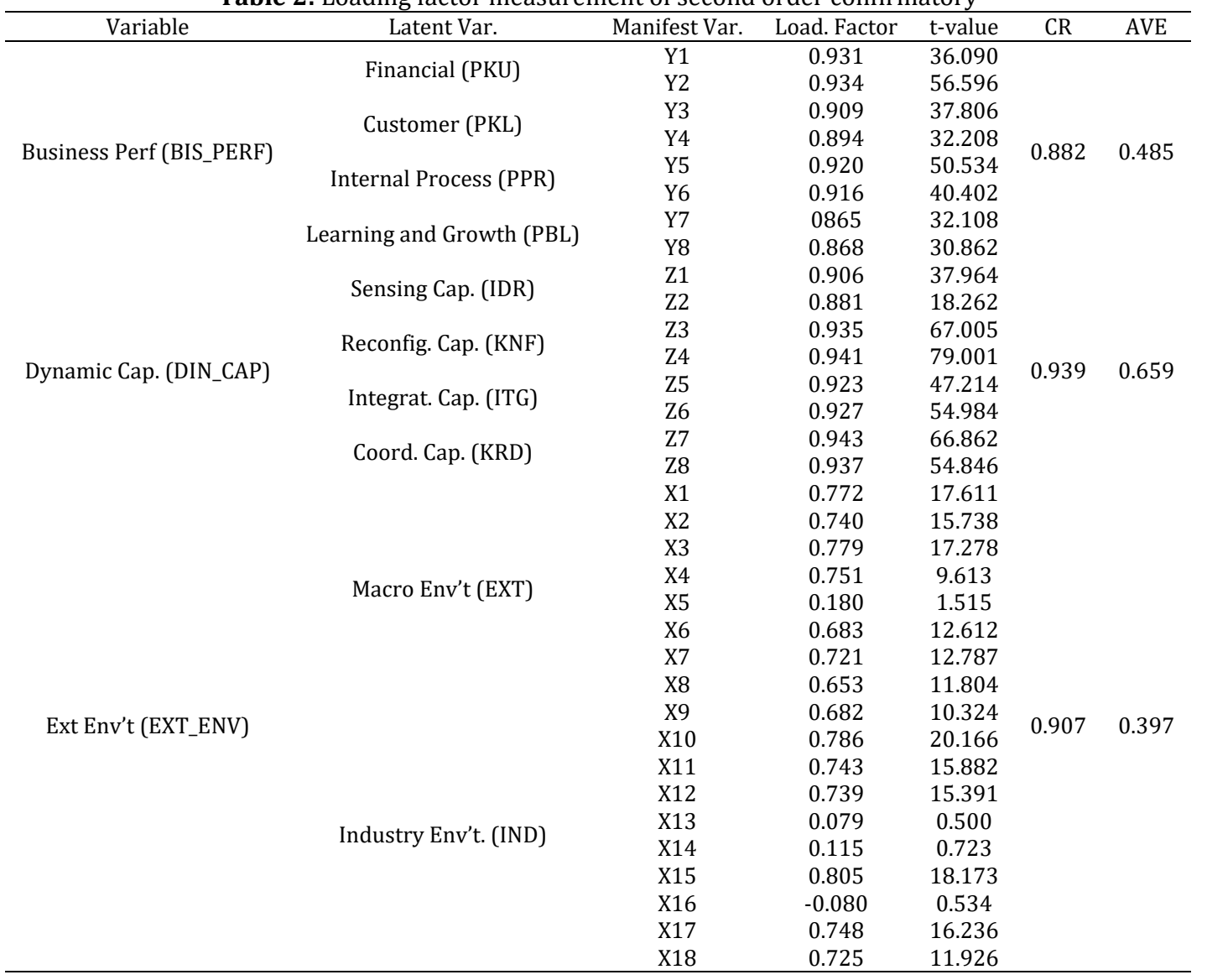

Table 2 shows that the loading factor on the measurement of the first order for the latent variable of financial perspective (PKU), customer perspective (PKL), internal process perspective (PPR), and the learning and growth perspective (PBL) is already valid and reliability in reflecting on these variables. This is indicated by the value of the loading factor for each manifest variable is greater than 0.5 , and the $t$ value $>1.96$. The indicators used are significantly able to reflect on the first order and second order in 
the construct of business performance. The value of the $\mathrm{CR}$ on the business performance construct is 0.882 above 0.7 . The value of the Average Variance

Extracted (AVE) is 0.485 showed that $48.5 \%$ of the information contained in the manifest variable (eighth indicators) can be reflected through the dimensions of the financial perspective (PKU), customer perspective (PKL), internal process perspective (PPR), and learning and growth perspective (PBL).

Furthermore, the value of the loading factor on the measurement of first order for latent variable of sensing capability (IDR), reconfiguration capability (KNF), integration capability (ITG), and coordination capability (KRD) shows that for each manifest variable is greater than 0.5 , and $t$-value $>1.96$. The indicators used are significantly able to reflect on the first order and second order in the construct of dynamic capability. The value of CR on the construct of capability is 0.939 . The value of AVE is 0.659 showed that $65.9 \%$ of the information contained in the manifest variable (eighth indicators) can be reflected through the dimensions of the sensing capability (IDR), reconfiguration capability (KNF), integration capability (ITG), and coordination capability (KRD)

Meanwhile, the external environment variables indicate that there are several indicators which have a loading factor below 0.5 , the indicator X5, X13, X14, and X16. The fourth indicator is then excluded from the subsequent analysis (drop-in) because it does not qualify for further analysis. The measurement of external environment latent variable indicated that the value of CR is 0908 and the value of AVE is 0397 $<0: 50$. Thus, the recalculation of the measurement model without these four indicators (drop-in) to obtain the value of CR and the AVE better.

After being dropped, the rest of the manifest variables in the external environment are 14 indicators comprising seven indicators of macro environment dimension (EXT) and seven indicators of industry environment dimension (IND). Based on the results showed that the loading factor for the manifest variable is greater than 0.5 , and the t-value $>$ 1.96. This means that the indicators used are significantly able to reflect the macro environment (EXT) and the industrial environment (IND) in the first order and construct the external environment (LNK_EKT) in the second order. The external environment has a CR value of 0935 . The value of AVE is 0.506 showed that $50.6 \%$ of the information contained in the manifest variables (14 indicators) can be reflected through the dimension of macro and industry environment.

\subsubsection{Structural model analysis (Inner model)}

Based on the analysis results of using SmartPLS version 3.0 obtained the structural model as shown in Fig. 1. Table 3 gives an overview of the influence between variables.

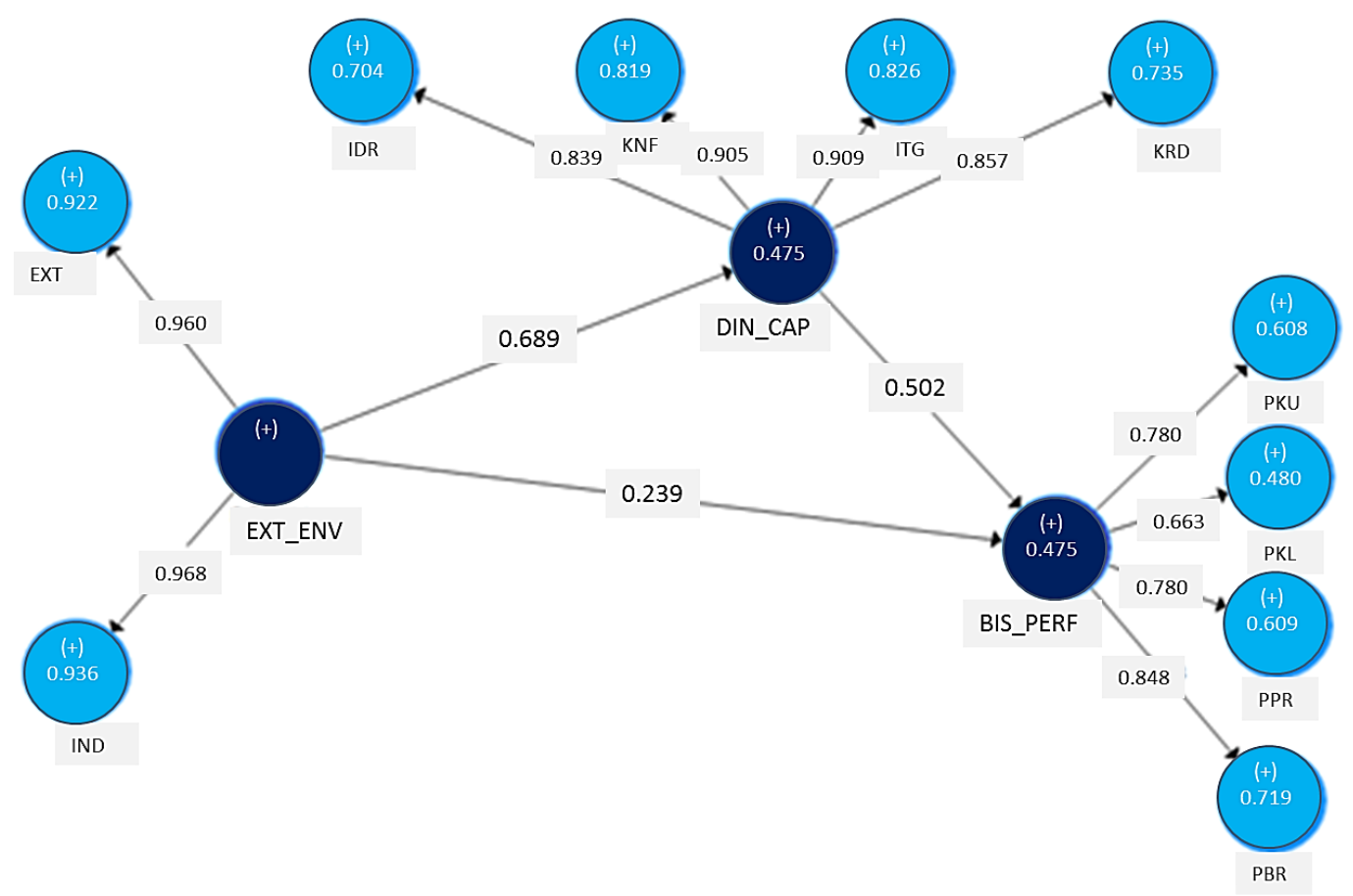

Fig. 1: Structural model

Table 3: The result of structural model measurement

\begin{tabular}{cccccc}
\hline Path & Path Coef. & $\mathrm{t}$-value & $\mathrm{F}^{2}$ & $\mathrm{Q}^{2}$ & $\mathrm{R}^{2}$ \\
EXT_ENV $\rightarrow$ DIN_CAP & 0.689 & 14.405 & 3.428 & 0.225 & 0.475 \\
DIN_CAP $\rightarrow$ BIS_PERF & 0.501 & 4.236 & 1.449 & 0.400 & 0.475 \\
EXT_ENV $\rightarrow$ BIS_PERF & 0.239 & 2.411 & 1.014 & & \\
\hline
\end{tabular}

The assessment of Good of Fit (GOF) in the structural model based on the criteria of the path coefficient, t-test, R-square, F-square, and Q-square. $\mathrm{R}$-square is an endogenous variable with a value of 
0.67 is categorized as "good", the value of 0.33 is categorized as "moderate", and a value of 0.19 is categorized as "weak". F-square value of $0.35,0.15$, and 0.02 respectively interpret whether latent variable predictor influence "large", "medium", or "weak". The criterion of Q-square value and path coefficient is positive and the t-test should be significant (Ghozali, 2008). Based on the test results indicate that the t-value $>1.96$ or all paths is significant, it can be concluded that this study has good inner model or good fit models. The R-square value shows that the external environment variable (EXT_ENV) gives the effect on dynamic capabilities (DIN_CAP) amounting to $47.5 \%$, while $52.5 \%$ the rest is the influence of other factors which are not observed. Furthermore, external environment (EXT_ENV) and dynamic capabilities (DIN_CAP) also exert influence jointly amounting to $47.5 \%$ on the business performance (BIS_PERF), while 52.5\% are influenced by other factors not observed. The results showed that the value of $\mathrm{R} 2$ on the three variables is the same; it is possible because of the similarity of the characteristics of each variable so that indicates that each variable has the same effect.

\subsubsection{Testing of verificative hypothesis}

Based on the hypothesis proposed in this study that the dynamic capabilities play a role as mediator towards the external environmental impact on business performance. The results showed that the dynamic capability is proven to have a greater influence as a mediator compared to the relationship of external environment directly to business performance as shown in Table 4 below. It is proved that the dynamic capabilities play an important role to improve business performance in the face of external environment changes.

Table 4: Relationship between variables

\begin{tabular}{ccccc}
\hline Relationships Between Variables & Direct Rel. & Indirect Rel. & Total Infl & \% Total Infl. \\
EXT_ENV $\rightarrow$ BIS_PERF & 0.239 & & 0.239 & 13.98 \\
EXT_ENV $\rightarrow$ DIN_CAP_ $\rightarrow$ BIS_PERF & 0.239 & 0.346 & 0.585 & 29.87 \\
\hline
\end{tabular}

Results showed that external environment is consisted of sub-variables macro environment and industry environment, significantly influence the success of the business performance. Theoretically it can be concluded that the external environment has a significant impact in determining the company's business performance. The results of this study are consistent with results from studies Guo and Wang (2014) who found that the external environment changes tend to improve the company's perception about environmental turbulence. The proper management in handling the external environment changes will provide a positive effect to the development of digital creative industry as a whole.

The study also shows that the dynamic capabilities as a mediator between the external environment and business performance are proven to deliver greater influence. Dynamic capabilities are the ability of the company in carrying out the strategy of aligning with the turbulent external environment change. Company management must be able to ensure that the dimensions of dynamic capabilities can be realized properly to support the achievement of business performance exceeds its competitors. Fernández-Mesa et al. (2013) found that the dynamic capability is obtained by studying the environment changes and enable the company to adapt to that change. Business performance is largely determined by the dynamic capabilities possessed, to capture the business opportunities arising from environmental changes. Based on the study of $\mathrm{Wu}$ et al. (2012) found that the dynamic capability enables the company to monitor the changing needs of various stakeholders, business opportunities, and reconfigure existing functional capabilities to the company's growth.
Digital creative industry should be able to capitalize when the macro environment condition continues to change dynamically, either of technological change, economic change, regulatory change, or social/cultural changes. Similarly, in addressing the industry's environmental change, especially on the threat of new entrants. The high level of incoming new entrant's due to the low entry barrier on the digital creative industries, the relative does not require huge initial costs, as well as the need for investment costs and fixed costs are relatively low. These conditions cause the businessman can easily leave the business because the exit barrier is also low. According to Evers (2011), dynamic capabilities for adapted and reorganized the product diversification strategy is a competitive advantage in an industry which is very competitive and turbulent. Business people in the digital creative industry should also be able to compete on various levels with other companies, where the company should be able to differentiate their products to produce a unique product, so as the products have a high difficulty to be imitated by competitors, and hard to be substituted with other products.

\section{Conclusion and recommendation}

The company's business performance is the outcomes of all business activities. Dynamic capabilities provide significant influence as a mediator between the external environment and business performance. It is indicated that organizations must manage dynamic capabilities to cope with changing external environment to business performance. The companies must be dynamically sensitive to perform sensing of 
environmental changes that occur either identified as threats or opportunities.

Based on this research, the digital creative industry in Indonesia is suggested to strengthen the dynamic capability management as a competitive advantage. Companies are advised to strengthen the ability to recognize changes in external environment, both macro environment consists of: political, economic, regulatory, and social/ cultural; and industry environment that include factors: bargaining power of buyers, bargaining power of suppliers, threat of new entrants, threat of substitutes, and the level of competition in the digital creative industry. In addition, the collaboration of actors in the quadruple helix model (academia, business, government, and communities) can improve the competitiveness strategy of creative content applications in Indonesia (Anggadwita et al., 2016). Governments and other stakeholders involved are expected to play a role in stimulating the MSMEs to get to know the business management digital-based, in addition to the MSME is a potential market for digital creative company in Indonesia, MSMEs performance will be more efficient and competitive with the use of digital technology.

\section{References}

Anggadwita G, Amani H, Saragih R, and Alamanda DT (2016). Competitive strategy of creative application content in ASEAN economic community: Software development using SWOT analysis in Indonesia. International Journal of Economics and Management, 10(S1): 95-107.

APJII (2016). Asosiasi Penyelenggara Jasa Internet Indonesia. Available online at: https://www.apjii.or.id/

ASPILUKI (2017). Asosiasi Peranti Lunak Telematika Indonesia. Available online at: http://www.aspiluki.or.id

Beamish HR, Hubbard G, and Rice J (2008). Strategic management, thinking analysis action. Pearson Education Australia, Australia.

BPSI (2016). Statistic Publication Official. Badan Pusat Statistik Indonesia [Central Statistics Agency, Indonesia], Indonesia. Available online at: www.bps. go.id

Deshpandé R, Farley JU, and Webster Jr FE (1993). Corporate culture, customer orientation, and innovativeness in Japanese firms: A quadrad analysis. The journal of Marketing, 57(1): 23-37.

Deshpandé R, Grinstein A, Kim SH, and Ofek E (2013). Achievement motivation, strategic orientations and business performance in entrepreneurial firms: How different are Japanese and American founders?. International Marketing Review, 30(3): 231-252.

Dess GG, Lumpkin GT, and Eisner AB (2006). Strategic management: Text and cases. Irvin/McGraw-Hill, New York, USA.

Eisenhardt KM and Martin JA (2000). Dynamic capabilities: What are they?. Strategic Management Journal, 21(10/11): 11051121.

Evers N (2011). International new ventures in "low tech" sectors: a dynamic capabilities perspective. Journal of Small Business and Enterprise Development, 18(3): 502-528.

Felier P and Teece D (2014). Case study, dynamic capabilities and upstream strategy: Supermajor EXP. Energy Strategy Reviews, 3: $14-20$.
Fernández-Mesa A, Alegre-Vidal J, Chiva-Gómez R, and GutiérrezGracia A (2013). Design management capability and product innovation in SMEs. Management Decision, 51(3): 547-565.

Ghozali I (2008). Structural equation modeling: Metode alternatif dengan partial least square (PLS). Badan Penerbit Universitas Diponegoro, Semarang, Indonesia.

Grant RM (2010). Contemporary strategy analysis. John Willey and Son Ltd., USA.

Gunter B, Furnham A, and Drakeley R (2016). Biodata (Routledge revivals): Biographical indicators of business performance. Routledge, Abingdon, UK.

Guo B and Wang Y (2014). Environmental turbulence, absorptive capacity and external knowledge search among Chinese SMEs. Chinese Management Studies, 8(2): 258-272.

Hitt MA, Ireland RD, and Hoskisson RE (2012). Strategic management cases: Competitiveness and globalization. Cengage Learning Company, Boston, Massachusetts, USA.

Jaworski BJ and Kohli AK (1993). Market orientation: Antecedents and consequences. The Journal of Marketing, 57(3): 53-70.

Kaplan RS and Norton DP (2006). Alignment: Using the balanced scorecard to create corporate synergies. Harvard Business Press, Boston, USA.

Lofsten H (2014). Product innovation processes and the trade-off between product innovation performance and business performance. European Journal of Innovation Management, 17(1): 61-84.

Mangematin V, Sapsed J, and Schüßler E (2014). Disassembly and reassembly: An introduction to the Special Issue on digital technology and creative industries. Technological Forecasting and Social Change, 83:1-9.

MIKTI (2016). Peta Industri Kreatif Digital 2015 Daerah Khusus Ibukota Jakarta. Indonesia Digital Creative Industry Community, Dinas Pariwisata DKI Jakarta, Jakarta, Indonesia. Available online at: mikti.id/

Mulyadi S (2003). Ekonomi sumber daya manusia dalam perspektif pembangunan. PT Raja Grafindo Persada, Jakarta, Indonesia.

Nieves J and Haller S (2014). Building dynamic capabilities through knowledge resources. Tourism Management, 40: 224232.

Pearce JA and Robinson RB (2008). Formulation, implementation, and control of competitive strategy. McGraw-Hill, New York, USA.

Pelham AM (2000). Market orientation and other potential influences on performance in small and medium-sized manufacturing firms. Journal of Small Business Management, 38(1): 48-67.

Rothaermel FT (2015). Strategic management. McGraw-Hill Education, New York, USA.

Saragih R and Anggadwita G (2016). Strategy competitive for creating sustainable growth in software development in Indonesia: A conceptual model. Procedia-Social and Behavioral Sciences, 219: 668-675.

Silalahi U (2012). Metode penelitian sosial. Refika Aditama, Bandung, Indonesia.

Teece DJ, Pisano G, and Shuen A (1997). Dynamic capabilities and strategic management. Strategic Management Journal, 18(7): 509-533.

TEMPO.CO (2016). Industri Kreatif Sumbang Rp 642 Triliun dari Total PDB RI. Deputi Riset, Edukasi, dan Pengembangan Badan Ekonomi Kreatif [Education and Development Agency Creative Economy]. Available online at: https:// m.tempo.co/read/news/2016/03/02/

Venkatraman N and Ramanujam V (1986). Measurement of business performance in strategy research: A comparison of 
approaches. Academy of Management Review, 11(4): 801814.

Walker OC, Boyd HW, and Larreche JC (1996). Marketing strategy: Planning and implementation. Irwin Industrial Tools, Huntersville, USA.

Wheelen TL and Hunger DJ (2012). Strategic management and business policy, toward global sustainability. Pearson/Prentice Hall, Upper Saddle River, USA.

Wu Q, He Q, and Duan Y (2012). Explicating dynamic capabilities for corporate sustainability: Evidence from corporate social responsibility reports. In the British Academy of Management Conference, Cardiff, UK. Available online at: http://uobrep.openrepository.com/uobrep/handle/10547/2 64293

Zahra SA, Sapienza HJ, and Davidsson P (2006). Entrepreneurship and dynamic capabilities: A review, model and research agenda. Journal of Management Studies, 43(4): 917-955.

Zollo M and Winter SG (2002). Deliberate learning and the evolution of dynamic capabilities. Organization Science, 13(3): 339-358. 